Laboratorio de Arte,1-1988 http://dx.doi.org/10.12795/LA.1988.i01.12

\title{
LA IGLESIA Y EL COLEGIO DE SAN BUENAVENTURA DE SEVILLA EN EL S. XIX
}

María José del Castillo y Utrilla

La Iglesia Conventual de San Buenaventura, y el Colegio de la misma denominación, no es un tema nuevo dentro del campo de la historiografía sevillana. No obstante, la versión que va a ocupamos, sí es inédita y original, y tiene el valor de ser un testimonio de primera mano, ya que es la descripción e historia que nos proporciona Fray Atanasio López de Vicuña, un curioso personaje que se instala en Sevilla a partir de la Restauración de la Provincia Bética Franciscana de 1881.

El autor a que nos referimos, viene al Convento de San Buenaventura como Superior (Guardián) y Definidor Provincial en los años inmediatos a la Restauración, más concretamente en 1889.

Debió ser sin duda un luchador incansable en la causa de la restitución a las Ordenes Religiosas de los bienes que se les había expoliado durante la Desamortización y otros sucesos del S. XIX, y así lo prueba el que al comienzo de muchos de sus escritos aparezca como lema: "Los Frailes en sus Conventos".

Es evidente que sus esfuerzos iban destinados a la reorganización de las Comunidades Franciscanas, y muy especialmente en las de la Provincia Bética a la que él pertenecía. De este afán surgiría con probabilidad, la idea de reconstruir, aunque fuera de una manera literaria, la historia y grandezas de las diferentes fundaciones de su Provincia.

Esta difícil reconstrucción histórico-artística, ocupa gran parte de los manuscritos que nos ha legado, y aunque muchas veces la erudición decimonónica de Fray Atanasio, hace que su prosa se nos presente un tanto farragosa, los datos que nos da, suelen ser fiables, cuando el autor trata de obras directamente conocidas por él, como es en el caso de San Buenaventura. 
Su actividad como escritor, no se centró exclusivamente en la narrativa histórica, ni en la descriptiva de los conventos de la Bética, sino que sus conocimientos generales, lo llevan a acometer una serie de obras de carácter diverso. Se incluyen en su autoría escritos de teología, sermonarios, hagiografias y doctrinales.

La nómina de su producción literaria, hasta 1897, fecha en que se data el manuscrito referente a San Buenaventura, es la siguiente:

1..-El Orador: o compendio de Literatura, Retórica y Oratoria.

2.?- - San José Conocido: Cuatro Septenarios.

3. . - La Inmaculada Concepción, explicada en 20 Sermones, con argumentos Bíblicos, Patrológicos, Escolásticos, Antropológicos y Místicos.

4. - - Apología de las Ordenes Religiosas en dos partes: la primera trata de la Naturaleza y Ventajas de la vida religiosa defendida contra los ataques incesantes de sus enemigos. La segunda de la Exclaustración y sus fatales consecuencias.

5. - - La Virginidad en noventa capítulos, dividida la obras en cinco partes.

6.9.-Historia del Convento de San Francisco el Grande de Sevilla y de San Buenaventura.

7.. - Historia de' San Francisco Solano en España.

8.?-Dos Novenas de San Antonio: 1.:: Su Vida. 2.: Nueve Coros.

Sirvan estas breves notas biográficas para presentar al autor del manuscrito del que vamos a tratar y ponernos en contacto con la personalidad del mismo.

En cuanto al Colegio de San Buenaventura y su iglesia, se fundó la institución en 1600, en unas casas de la actual calle García de Vinuesa, aunque su establecimiento definitivo, en el lugar que hoy ocupa, no tuvo lugar hasta 1605. Para este fin, la comunidad del Convento de San Francisco cedió una parte de la huerta de la Casa Grande.

El Colegio de San Buenaventura se fundó por tanto en terrenos del convento franciscano, pero con total independencia del mismo.

Su estatuto era el de "Propaganda Fide", que suponía un sistema de fuerte preparación teológica de sus miembros, especialmente dedicados a la defensa y expansión de la Fé Católica, sistema perfectamente entroncado en el espíritu tridentino y muy necesario para la formación de tantos franciscanos, sobre los que caía la responsabilidad de la evangelización, no sólo en gran parte de España, sino también en América, Filipinas y Tierra Santa. A este 
aspecto misional de la Orden, hay que añadir la labor docente que llevaba a cabo en diferentes Estudios Generales, ocupando sus miembros diferentes cátedras, sobre todo de Teología y de Sagradas Escrituras, lo que requeria, insistimos, un alto nivel de preparación intelectual en los frailes destinados a estos fines.

Supuestas ya estas bases de conocimiento tanto del autor como de la institución de que vamos a ocuparnos, pasemos a ver lo que acerca de la misma nos dice Fray Atanasio López de Vicuña.

Texto: (Transcripción directa del manuscrito)

\section{COLEGIO MAYOR DE SAN BUENAVENTURA DE PROPAGANDA FIDE}

Este Colegio fue de los más celebérrimos de la Orden Seráfica por los muchos y sapientísimos Religiosos que de él salieron. Fue fundado en el año de 1600.

El M. R. P. Fray Luis Rebolledo, Lector Jubilado y Provincial de esta Provincia, quiso fundar en esta ciudad una cátedra y Colegio de nuestra Orden a imitación de la de Alcalá de Henares, en que sólo se tratan de Letras y Estudios mayores de ciencias Sagradas, con la advocación del Seráfico Doctor San Buenaventura. Más tarde escribiré la biografía detallada de este insigne varón cuyo espléndido retrato nos dejó pintado y escrito el Inmortal Pacheco.

Mirando el estado topográfico de Sevilla entre toda esta Provincia y la facilidad de comunicarse por mar con las Provincias del Norte y de Ultramar y con los demás Continentes por navegación, conocido este convento en todo el mundo por el número de sus hijos que enviaba hasta los confines de la tierra y por lo tanto viendo la facilidad de que podía disponer la Provincia para sus jóvenes más aventajados que no tenían facilidad o medios de desarrollar su ingenio y hacerse hombres de mayor peso y gloria para la Orden y la Iglesia, estableció este Colegio a la altura de los más célebres del universo.

Propuso su pensamiento al definitorio y aprobado su dictamen se escribieron los medios para alcanzar el beneplácito del Capítulo General que entonces se celebró en Roma. Fue solemnemente aprobado en el Capítulo y se pensó en realizar el pensamiento tan gigantesco. Dios allanó las dificultades. Vivía en Sevilla una piadosa Matrona llamada Doña Isabel de Siria, viuda de Don Andrés de Corso de Casuche, noble de la Isla de Córcega 
y vecino de esta ciudad. Tomó a su cargo y compró para ello en la calle la Mar las casas correspondientes a donde después estuvieron las casas de la escuela.

Auxiliola en los gastos y empresa Don Tomás de Mañara, padre de Don Vicente (sic) de Mañara, fundador del Hospital de la Caridad de Sevilla establecido junto a la Maestranza y el río Guadalquivir.

No satisfacía este plan al intento de los Religiosos porque tenían que salir de su Convento para ir a esas aulas. Por eso, se sacrificó una parte de la Huerta del Convento de San Francisco y se hizo, en el espacio que iba desde la calle Vizcaynos a la calle Catalanes en 1605, el magnífico edificio, con sus tres patios y su Iglesia, independiente, que daba a la misma calle Catalanes.

Los tres patios formaban un magnífico frontis a la huerta y por ella se comunicaba el Convento Mayor y el Mayor Colegio.

La entrada la tenía por la calle Catalanes junto al Homo de Nieto y a la capilla del Sagrario, que estaba bajo el coro de la Iglesia de San Buenaventura, donde hoy está la calle Bilbao. Como el pasadizo que los revolucionarios de 1840 dejaron era muy estrecho y le llamaron calle de Cádiz, en 1846 el Ayuntamiento de Sevilla autorizaba que se derribase la capilla citada de la Iglesia, cuyos arcos aparecen todavía con la puerta alta del Coro en la esquina de la calle Bilbao. Así profanaron esta Capilla donde estaban enterrados tantos santos religiosos entre otros el P. Pay estaba enterrado en la última capilla junto a la calle Catalanes, que era el Sagrario, y en la del Patrocinio de hoy, que era la de San Antonio, y donde está enterrada la gran bienechora de Sevilla, la Condesa de Lebrija.

Al Convento se entraba por una puerta junto a la de la Iglesia, que es el callejón que hemos referido; a la izquierda estaban las dos Enfermerías, alta y baja, hoy a la espalda de la Virgen del Carmen y de la Soledad y donde vivió el Cónsul de Chile.

Antes de llegar al claustro, estaba a derecha la entrada de la Iglesia, donde hoy está el ricón del altar del Patrocinio y el reloj. Ya no se ve aquí más que la puerta falsa que va hacia la Sacristía detrás del Altar Mayor.

Se llegaba a un zaguán o cancel y aquí está todavía un tránsito o corredor muy largo y espacioso y había habitaciones y libratorios de cada lado. Hoy se ha cerrado esta puerta por sus propietarios, pero el tránsito es el mismo.

De aquí se llega al patio principal, muy espacioso y alegre. Sus claustros o corredores están adornados con arcos y columnas de mármol, es casi cuadrado; a la izquierda del lado del sur está todavía la magnífica escalera 
de jaspe rojo. En la puerta estaba colocada una hermosísima figura de la Inmaculada Concepción. La parte de arriba corresponde a la de abajo, lo único que han hecho es derribar los tabiques de las celdas para hacer grandes salones corridos. Tiene sus dos pisos superiores con sus cinco ventanas en cada uno y dan a la calle Madrid, del lado de la calle Catalanes y Bilbao tienen tres ventanas en cada piso y su azotea es hermosa. Todavía se conserva parte del oratorio interior.

Nota: "Los que vendrán después nos echarán en cara por qué no compramos este claustro y no la casa tan reducida que se ha comprado del otro lado de la Iglesia. A esto respondo que, en efecto, pensamos comprarlo, pero nos exigian cuarenta mil duros y eso no los vale. $2 .^{9}$, que la casa es chica y no puede extender a ningún lado y sólo podían caber dieciséis Religiosos y esto no era noble ni suficiente para la casa franciscana de Sevilla. 3.?, porque como da esta casa a una única calle, en los momentos de revolución; los amotinados para defenderse y huir al enemigo buscarian esta casa como dijo Narváez y expondrían siempre a los Religiosos o a juzgarlos cómplices o a echarlos a fuerza de su casa."

Sigamos nuestra descripción saliendo de este primero y principal claustro a derecha hacia la calle Zaragoza estaba otro patio con el Refectorio y Deprofundis y arriba tenía el Dormitorio. Este patio está hoy en la casa de Pickman. Al hacerse la obra se encontraron donde estaban los claustros muchos esqueletos porque en ellos se enterraban los Religiosos como se ve en las sepulturas de los claustros de nuestro Convento de la Rábida.

Enmedio de este patio estaba un hermoso aljibe. Me dijo Dona Reyes, hermana de la Marquesa de Pickman, la cual se educó en esta casa al salir de aquí los religiosos, que se acuerda todavía cuando ganaba el Jubileo de Porciuncula.

En fin, seguía el tercer patio que llegaba casi a la calle Zaragoza y terminaba allí la Huerta, en la bocacalle donde hoy está una Farmacia y un poco más-abajo hacia la calle Palenque, donde estaba la callejuela llamada de San Buenaventura estaba la noria movida por un borrico.

En estos tres patios tenían su respectiva celda que daba a la huerta y al Levante, el Rvdo. Padre Guardián, el Regente de Estudios, los cuatro lectores, los doce Padres estudiantes privilegiados y los legos.

La huerta iba desde este último patio hasta donde hoy se ve la casa de Santa Teresa y continuaba el muro hasta calle Tintores o esquina de la Fonda de la Victoria.

El Convento de San Buenaventura estaba junto a los muros antiguos de Sevilla, pues lo más que hay son sesenta pasos desde la entrada de la calle 
Palenque (donde se unía con San Buenaventura) hasta la Plaza de Molviedro y en frente está la casa del Sr. Marqués de Morant y allí se han encontrado los muros antiguos que sirven todavia por el lado del Poniente de muro de esta casa y calle, llamada todavía de la Laguna y se juntaba con la calle Cantarranas, hoy Gravina, en la misma Puerta de:Triana o de Trajano, o de Julio César, cuyo arco se destruye en estos años junto a la calle Santas Patronas, donde vivieron las dos humildes alfareras Santa Justa y Santa Rufina; Vírgenes y Mártires, Patronas de Sevilla.

La Librería de San Buenaventura era riquísima. Sólo han venido a mis manos dos secciones de sus obras, 0 de su índice; la primera que trata de los autores cronistas o la sección de Derecho, y la segunda la sección de Scritoria. Por estos trozos o índices podemos juzgar de la riqueza incomparable de nuestra librería. Esta librería fue hecha por el famoso Fray Blas de Benjumea, cuya biografia publicaré más tarde con sus obras. Murió en 1679.

\section{DESCRIPCION DE LA IGLESIA DE SAN BUENAVENTURA}

El Templo de San Buenaventura forma una sola y espaciosa nave cuya arquitectura pertenece al orden jónico y aún conserva en la media naranja y pechinas algunos buenos frescos de Herrera el Viejo. Formaba sin embargo una especie de crucero incompleto con su media naranja de 24 metros de alta y diez hasta la cornisa como se midió para comprar la cuerda que empleamos en las tres arañas que hemos comprado para adornarla.

Desde el corredor detrás del altar mayor hasta la puerta de la Iglesia tiene treinta y cuatro metros de largo. El pavimento es de losetas antiguas de Génova, blancas y negras: tiene un coro alto muy espacioso, al cual se entraba por el lado del Evangelio entre las dos capillas que formaban bajo el coro el Sagrario. Hoy, comprada la casa del lado opuesto, entramos por allí enfrente de la antigua puerta.

Después de la entrada de los franceses en Sevilla destinaron esta Iglesia para cuadras de caballos (ipaciencia, Dios!) y quemaron el retablo y altares. Fue restablecida la Iglesia en 1814 pero los masones arrojaron de nuevo a los religiosos de San Buenaventura en 1821 y sirvió de museo hasta 1824 en que Fernando VII ya libre de los constitucionales devolvió su iglesia a los religiosos y los dejó volver a sus conventos.

Entonces sólo pudieron arreglar el altar con alguna pilastra, colocando en el pequeño altar mayor una Inmaculada Concepción que hoy se venera en el mismo Sagrario de San Buenaventura. 
Cuando en 1856 se puso el retablo que hoy existe hecho entonces para la Iglesia de los Mercenarios, pero no pudiéndose colocar allí porque la Iglesia fue destinada para Museo, los padres franciscanos lo compraron y lo colocaron aquí, habiendo trabajado en la obra mi buen antiguo amigo ebanista José Femández, Hermano de las Directoras Dolores y Concepción, quizá hizo también el retablo hermosísimo del Sagrario y trabajó en la colocación del altar de la Virgen del Patrocinio, que vino del derribado templo de San Francisco.

Como hemos insinuado había dos capillas y formaban un crucero. La del lado del Evangelio, donde está hoy la Virgen del Patrocinio con San Roque y N. S. P. San Francisco, es ya el de la V. O. T., era más pequeño que hoy y estaba destinado a San Antonio de Padua. Aquí se enterró la Sra. Condesa de Lebrija, que nos dejó cada año en su testamento, administrado por la Junta de Beneficencia setecientas cincuenta pesetas para misas y funciones en San Buenaventura. Junto a este altar estaba la entrada de la iglesia para los Religiosos en las procesiones claustrales.

La Capilla del lado de la Epístola era también tránsito a la Sacristía, pero tenía un altarcito donde estaba San José y otro donde estaba la Virgen del Carmen llamada "de la batata", porque su cofradía pobre la veneraba en el Postigo del Aceite y con batatas y otras hortalizas rifadas, le celebraban sus cultos. Destruida aquella capillita se trasladó la Virgen a San Buenaventura.

En el mismo altar de San Antonio en el lado del Evangelio y junto al púlpito estaba también la Santísima Trinidad. Aquí está enterrado el famoso Padre Regente Fray Marcos Xisto Maestre.

Cuando se trajo la Virgen Sevillana a San Buenaventura, se trasladó la Purísima que estaba en el altar mayor al Sagrario, como dijimos refiriendo su gloria.

Como en algunas memorias y libros se habla de algunos altares de San Buenaventura y de los entierros que delante de aquellos altares tenían los bienhechores, bueno será que siga el orden que antes tenían los altares con el que hoy guardan. Donde está hoy la Virgen del Carmen a la derecha del púlpito, estuvo en tiempo la Purísima que hoy está en el Sagrario hasta que se hizo el corredor que hoy viene de la Sacristía a la Iglesia por donde venía la calle de San Buenaventura y se abrió esta puerta en frente del púlpito, donde hoy está la Soledad, preciosa escultura hecha hacia 1840 por Astorga, que también retocó a la Virgen de Loreto y le puso los ángeles que compró para ella Doña Manuela Illanes, que vivía en el Loreto con el Padre Miguelito. Esta Señora se sacrificó y se sacrifica por el Loreto. Hoy vive todavía en Umbrete. 
Estaba la Coronación de María, o sea, el medio punto que hoy está bajo el coro, es una de las esculturas más acabadas. Donde está hoy San Antonio estaba el altar del Santo Angel Custodio, llevado a la parroquia de Santa Lucía, junto al Valle y que hoy es fábrica de cuchillos, y San Antonio estaba donde hoy está la Virgen del Patrocinio y en este sitio o capilla se enterró la Condesa de Lebrija, por lo tanto en la acera de la calle Bilbao, pues allí se extendía la capilla y hoy se ve el arco.

El patronato de la Señora Marquesa es el más pingüe que administra la Junta de Beneficencia, la ciudad percibe más de cincuenta mil reales anuales.

Donde hoy está el Santo Cristo de la Humildad y Paciencia en actitud de estar sentado cuando barruntaba la cruz y abrían el hoyo los verdugos, era la entrada del Sagrario y en este rincón estuvo algún tiempo dentro del Sagrario la Virgen del Carmen, donde hoy está la Virgen de la Esperanza con su áncora en la mano y traída de San Francisco, estaba el altar de San Miguel que se venera hoy en un nicho del presbiterio, del lado del Evangelio junto al reloj. Donde hoy está la Virgen de Lourdes, cuya gruta nos costó tres mil reales en Abril de 1891, y que para hacer la capilla se abrió el muro de la Iglesia y se aprovechó el terreno que era antes calle de San Buenaventura estaba al lado del Santo Cristo de la Humildad y Paciencia.

San Buenaventura estaba donde hoy se venera, cerca del Sagrario, del lado de la Epístola. Es una de las esculturas más encantadoras. Tiene su santo hábito bordado en oro finísimo y antiquísimo que se le pone para la fiesta y triduo que le celebra hace ciento cuatro años, desde que se estableció la adoración perpetua en Sevilla: Lleva alas como símbolo de su ingenio, tiene en su mano izquierda un templo de plata con el birrete de Doctor con sus lindísimas borlas y muceta encarnada de Cardenal de un bordado y dibujo del mejor gusto. Mi grande amigo Don Pablo Beauchy y Boyer de Galindo sacó unas preciosísimas fotografías (tal como está en su altar el día de su fiesta, 14 de Julio de las cuales remití algunas a todos los conventos de la Provincia para animar a los estudiantes. (El chichet está en casa del fotógrafo Beauchy y otro en el Convento.)

La Virgen de Belén que está bajo del Coro, vino de San Francisco y también el Santísimo Cristo de la Buena Muerte. San José estaba en su capillita.

Los franceses dejaron casi destruidos el Templo y su convento, y en los años de 1813 y 14 emplearon los padres para restaurarlo treinta mil reales, como aparece en las cuentas que el R. P. Fray Antonio Ruiz, Guardián del Convento, presenta al Capítulo Provincial. 
La hermosa Custodia de plata sobredorada que teníamos se la llevaron los franceses y la pudieron coger en Zalamea por la dedicatoria que tiene y la Iglesia donde servía. Desde 1813 al 20 fueron reparando los religiosos los desperfectos pero el gobierno de 1820, presidido por Argüelles y Riego, tomando al Rey con pretexto de que estaba loco, lo encarcelaron en Cádiz hasta que en 1823 su juez del congreso de Verona el Duque de Angulema, que lo defendía, vino al frente de cien mil hombres, lo sacó de las garras de los Constitucionales y Masones, llevándolo desde Cádiz a Madrid.

En este intervalo sólo se nos dejó más que once conventos de treinta y seis que tenía la Provincia y la Iglesia de San Buenaventura servía de Museo. Anuló todos los decretos que firmó por fuerza Fernando VII y volvieron los religiosos a sus conventos. Los masones no dejaron de perseguirlos hasta que vinieron los fatales decretos de 1834,5 y 6 , por los cuales se arrojó a todos los religiosos de España. En 1840, Espartero, habiendo destronado a Cristina, que huyó de España a Inglaterra con el incógnito de la Condesa de Vista Alegre, dejándonos sólo diez Obispos en España, y treinta y seis desterrados, bombardeó a Sevilla. En estos tiempos sirvieron como cuarteles a los dos partidos opuestos, los conventos de San Francisco y San Buenaventura.

El General Narváez se apoderó del claustro y convento de San Buenaventura y de aquí hacía fuego a los que estaban en las ruinas y cuartel de San Francisco. (Velázquez, Alanes de Sevilla, pág. 479-492.)

\section{PINTURAS DE LA IGLESIA DE SAN BUENAVENTURA:}

Antes de la invasión de los franceses había cuatro grandes pinturas de Zurbarán que figuraban pasajes de la vida del Seráfico Doctor, todo se perdió en la francesada y fueron adomar los museos de Francia. Allí se glorian con lo que robaron a los ignorantes frailes españoles.

La media naranja está pintad por Herrera el Viejo. En la cúpula de esta media naranja sobre el crucero se pintaron en la misma bóveda (y por ser los frailes tan finos y previsores no pudieron los enemigos llevarse estas pinturas) con sus respectivos rótulos San Francisco de Asís, San Luis de Anjou (hijo de Carlos II Rey de Sicilia y obispo de Tolosa a los 23 años), San Bernardino, San Jacome de la Marca y San Pedro de Alcántara.

En el presbiterio del lado del Evangelio están los magníficos cuadros de San Diego de Alcalá y San Luis Obispo y del lado de la Epístola el de San Pascual Bailón, también sobre el arco del Sagrario está un grandioso cuadro representando al Venerable Juan Duns Scoto al salir del convento con otros 
religiosos que llevan la bandera de la Inmaculada Concepción con las palabras "Me duce" se postra de rodillas ante la Virgen de mármol que inclina la cabeza en señal de cariño y protección en el acto público de la Universidad de París a donde iba a sostener la "Igvinio Minora" sobre la Inmaculada Concepción contra tantos Doctores contrarios.

En los cuatro ángulos de la media naranja hay un medallón, el del lado de la Epístola sostenido por un Angel, dice así: "Videbant descendentem gloriam Domini super domun hanc". El medallón del lado del Evangelio, sostenido por otro Angel dice: "Domino de luxi decorem domus tua". Donde arrancan los nervios de la media naranja están los escudos de los fundadores, entre ellos del lado de la Epístola aparece un magnífico León en campo de oro, escudo de los Guzmanes.

En la bóveda de la Iglesia se pintaron los ocho principales doctores de nuestra orden Seráfica. El que está del lado del Evangelio sobre el púlpito es Alejandro de Alés y el que está enfrente del lado de la Epístola Fray Ricardo de Mediavilla. Siguen del lado del Evangelio Fray Juan Moairon, Fray Pedro Aurcolo y Fray Nicolás de Lyra, y del lado de la Epístola Fray Guillermo Orckam, Fray Francisco Ligueto y Fray Francisco Titelman.

Entre unos y otros en medio de la bóveda están los símbolos bíblicos de los Doctores, como la Fuente, la Concha, la Pluma.

Toda esta Iglesia, sus cornisas y las girnaldas que la adoman y se entrelazan caprichosamente, y todos los machones estaban dorados, como apareció cuando tuvimos que descarnarlos por la parte de abajo para colocar el alicatado en 1894. Alguna mano poco inteligente lo encaló y embarrunó todo con cal de Morón, tal vez porque los caballos, los franceses y el humo, lo dejarían muy feo.

Hasta aquí el relato de Fray Atanasio López de Vicuña y las noticias que aporta su manuscrito.

La historia breve que este fraile nos hace acerca de San Buenaventura está llena de sugerencias para acometer una investigación profunda sobre el tema, idea que no desechamos, pero que en esta ocasión no podemos realizar por razones obvias. No obstante, no podemos sustraernos a la tentación de hacer unas cuantas comparaciones ligerísimas, como lo requiere el momento, que pongan en paralelo el estado de la obra en el siglo XIX, y las condiciones actuales de la misma, sin pretender en absoluto, como decíamos, profundizar en el tema, de por sí bastante amplio. 
A lo largo de casi los cien años que han transcurrido desde que Fray Atanasio redactara su obra hasta el presente, han sido varias las alteraciones que ha sufrido este conjunto franciscano, tanto en lo que corresponde al recinto conventual como a su Iglesia, y en ésta, que es en la que insistiremos como muestra, no sólo en lo que se refiere al exorno y distribución de capillas, retablos e imágenes, sino también respecto a su misma disposición arquitectónica.

Mientras el convento actual sigue en líneas generales lo que el cronista nos apunta en su plano (Fig. 1), como "Convento Nuevo", en la Iglesia es donde encontramos sin duda los cambios más evidentes en relación con la crónica de la que nos venimos ocupando.

Hasta los años treinta del presente siglo, su disposición se acopla a la que se le dio en la restauración, entre 1881 y 1897 (Fig. 2).

Se mantenía la nave única, con sus altares adosados a ambos lados, y el retablo neo barroco, procedente de los Mercedarios, obra del ebanista José Fernández (Fig. 3).

Aunque aquí se habla de una Iglesia de una sola nave, en origen lo fué de tres. Se reabrió en la reforma última la del lado de la Epístola, pero la del lado del Evangelio se había destruído en 1863,para abrir la calle Bilbao.

Actualmente, el recinto eclesial cuenta con una nave de tránsito colateral al lado de la Epístola, que está desprovista de altares, si prescindimos del solio que alberga al Stmo. Cristo de la Salvación.

En esta nave colateral se abre la Puerta Reglar, que comunica con el patio y claustro, y también encontramos en ella la puerta que da acceso a la antesacristía. Al fondo de esta nave, se encuentra la capilla del Sagrario, adornada por dos retablos, muy posiblemente los que López de Vicuña atribuye a José Fernández: el del Sagrario propiamente dicho, que hoy está presidido por la Virgen de Guadalupe, y alberga además las imágenes de San Francisco y de San José (Fg. 4), y otro, de la misma factura, en el que se encuentra Ntra. Sra. del Patrocinio, obra del s. XVIII, que perteneció a la V.O.T.

El retablo mayor actual tampoco es el mismo del que nos habla el cronista. Durante las reformas que registró el templo en los años cincuenta, se instalo en el presbiterio un magnífico retablo barroco, procedente de las Concepcionistas de Osuna. En el camarín, se colocó la imagen de la Concepción Sevillana (Fig. 5), que actualmente lo preside, y en los intercolumnios y pedestales, se situaron diferentes figuras de Santos y Angeles de procedencia varia, entre ellos se encuentran el San Miguel y el 
San Roque, a los que hace alusión López de Vicuña cuando nos habla del altar del Patrocinio de la V. O. T., además del Santo Domingo y el San Francisco que estaban en el retablo antiguo. En su conjunto, la obra que hoy preside el templo franciscano, es una muestra magnífica del barroco sevillano. (Fig. 6)

En el lado del Evangelio es donde se encuentran el conjunto de los altares, algunos de los cuales albergan imágenes de las que hace referencia la crónica. Comenzando por los pies del templo, está la Coronación de la Virgen, debajo del coro, un magnífico relieve del S. XVIII. Le siguen, bajo arcos rehundidos en el muro, el altar del Sagrado Corazón, el de San Antonio de Padua, con su retablo neobarroco, coronado por la figura del Padre Eterno, el de la Inmaculada Concepción (Fig. 7), que estuvo situada en el retablo mayor, hasta que fue sustituída por la Sevillana. Continúa, en un retablo también barroco, aunque de factura reciente, la Virgen del Carmen "de la batata", y por último, el altar de Ntra. Sra. de la Soledad, la conocida imagen de Astorga.

Esta es la relación de imágenes que actualmente se veneran en el templo franciscano, como podemos comprobar, solamente seis existian en tiempos de Fray Atanasio, y, por supuesto, el lugar que ocupan ahora no se corresponde con el que nos indica el cronista.

Se han perdido, o al menos no se encuentran en San Buenaventura, varias de las citadas en el manuscrito, que son: la Virgen de la Esperanza, el Cristo de la Humildad y Paciencia, San Buenaventura, la Virgen de Belén, el Cristo de la Buena Muerte y, por último, la Virgen de Lourdes, habiendo desaparecido también la gruta que había sido construida para ella en 1892.

No queremos alargar esta serie de comparaciones, que nos llevaría a un catálogo penoso y desabrido. Basta el muestreo que hacemos para intuir la importancia del tema y la necesidad de emprender un estudio serio y profundo sobre el mismo. Empresa que (D. m.) se llevará a cabo a su tiempo. 


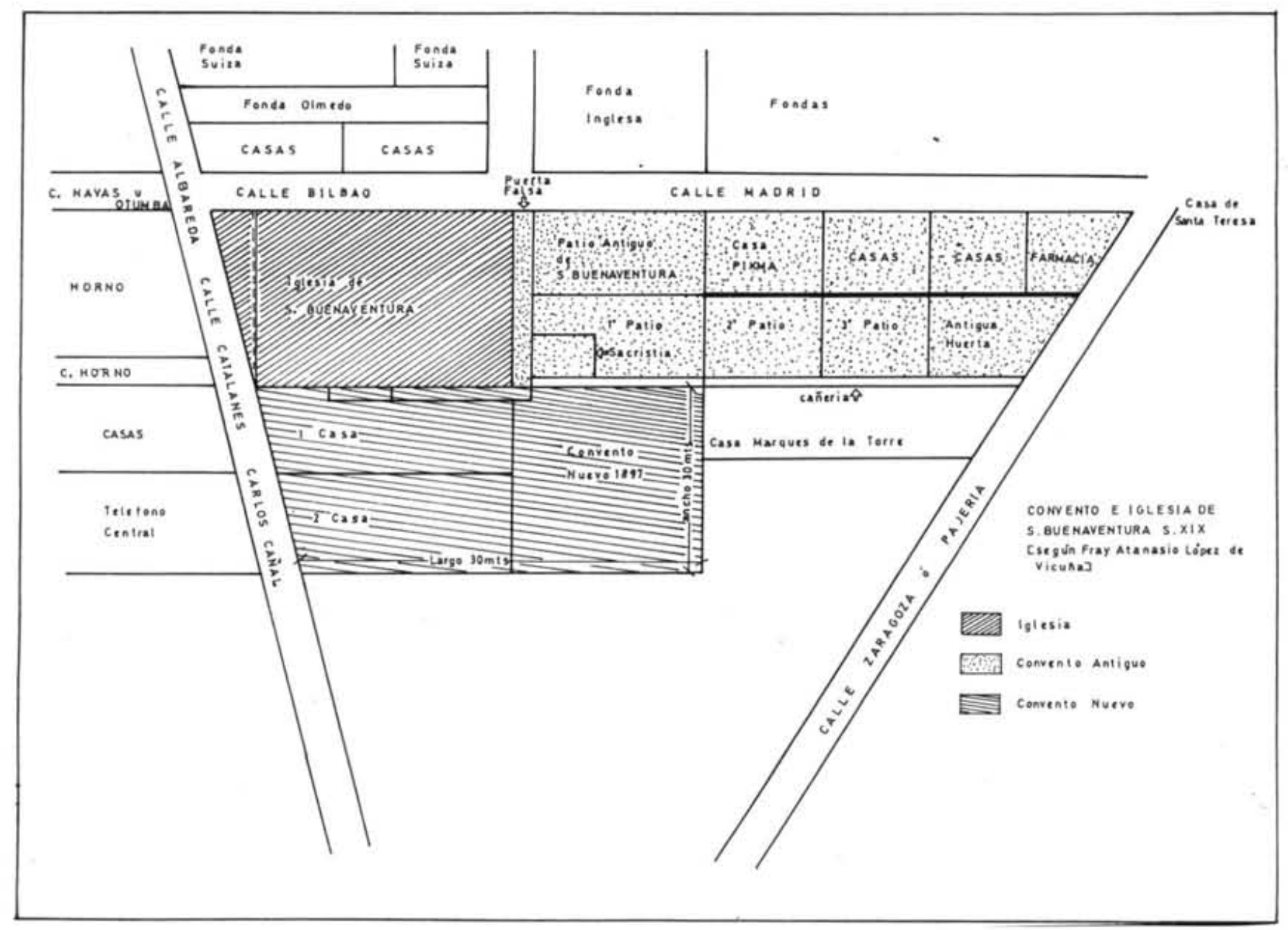

Fig. 1. Plano de San Buenaventura, según Fray Atanasio López de Vicuña. 


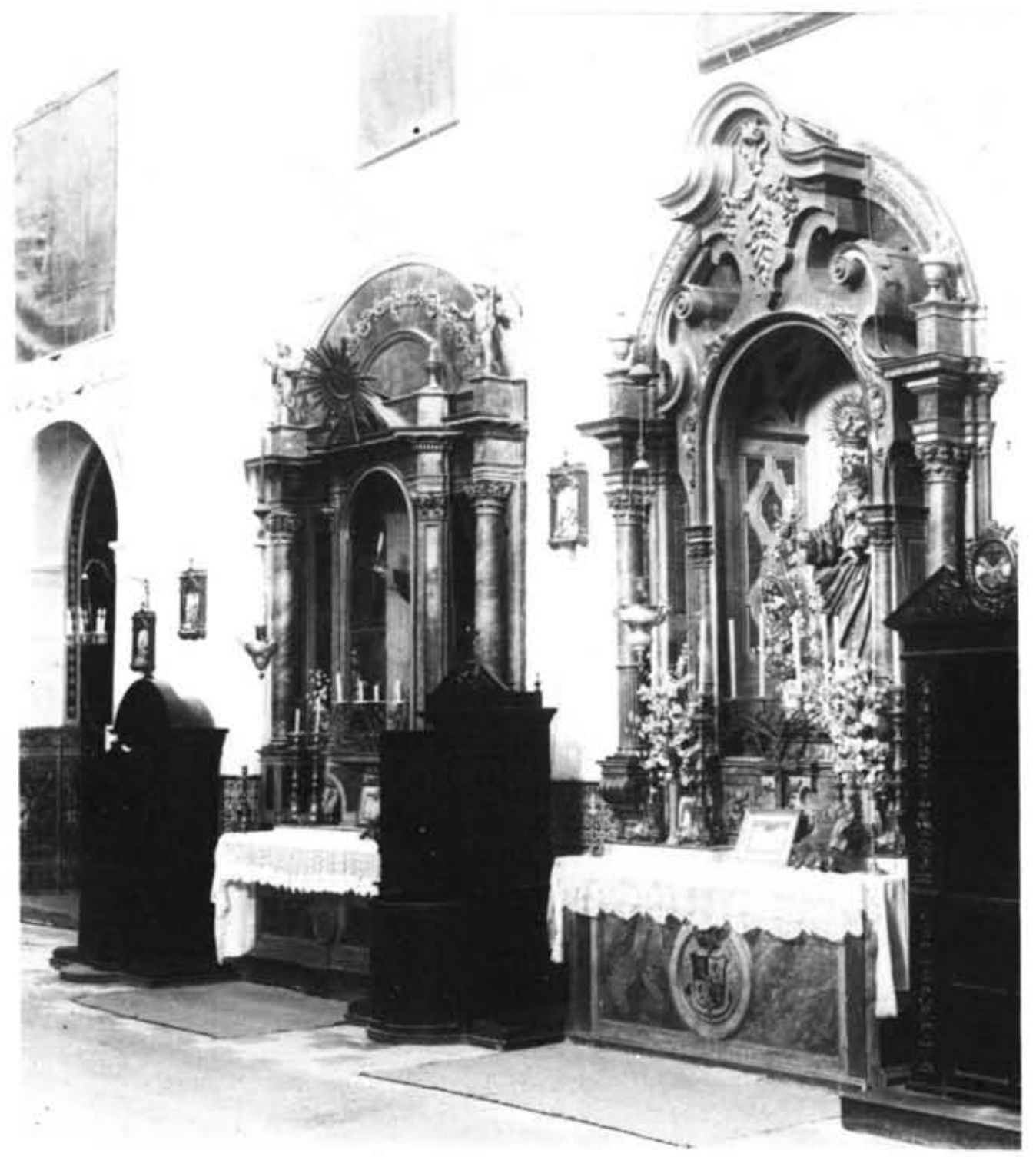

Fig. 2. Iglesia de San Buenaventura de Sevilla. Altares del lado de la Epístola, hoy desaparecidos. Corresponden a los que López de Vicuña identifica como de la Virgen de la Esperanza y de San Buenaventura. Foto Nandin 30-10-1930. (Cliché: Laboratotio de Arte). 


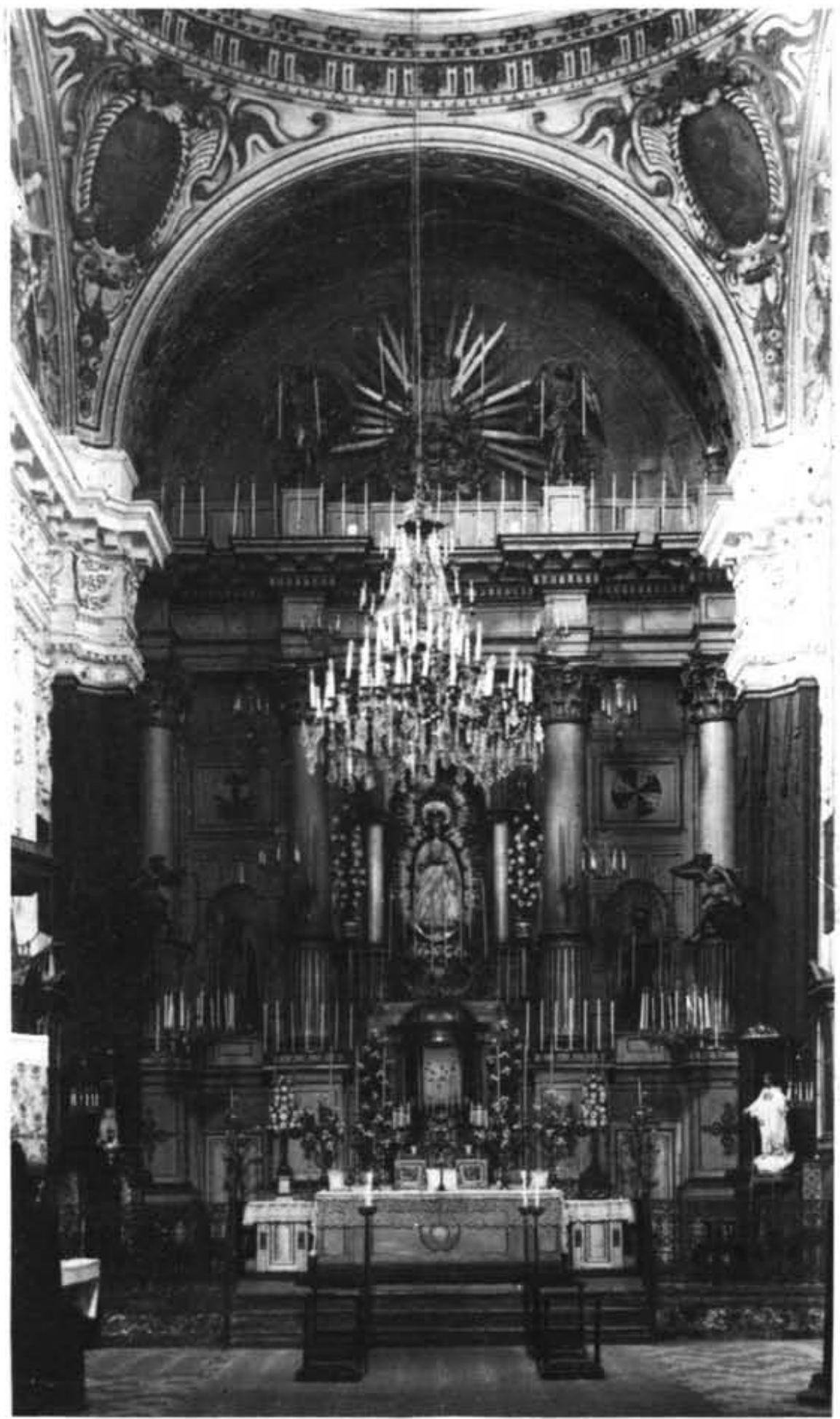

Fig. 3. Presbiterio y Retablo Mayor de San Buenaventura de Sevilla. El retablo es el que se instaló en el s. XIX, obra de José Fernández y que en su origen estaba destinado a la Iglesia de los Mercedarios. Foto Nadín: 30-10-1930. (Cliché: Laboratorio de Arte). 




Fig. 4. Retablo de la Capilla del Sagrario de la Iglesia, de San Buenaventura. Este pertenece a la mano de José Fernández, lo mismo que el que en la misma capilla alberga a la Virgen del Patrocinio. 


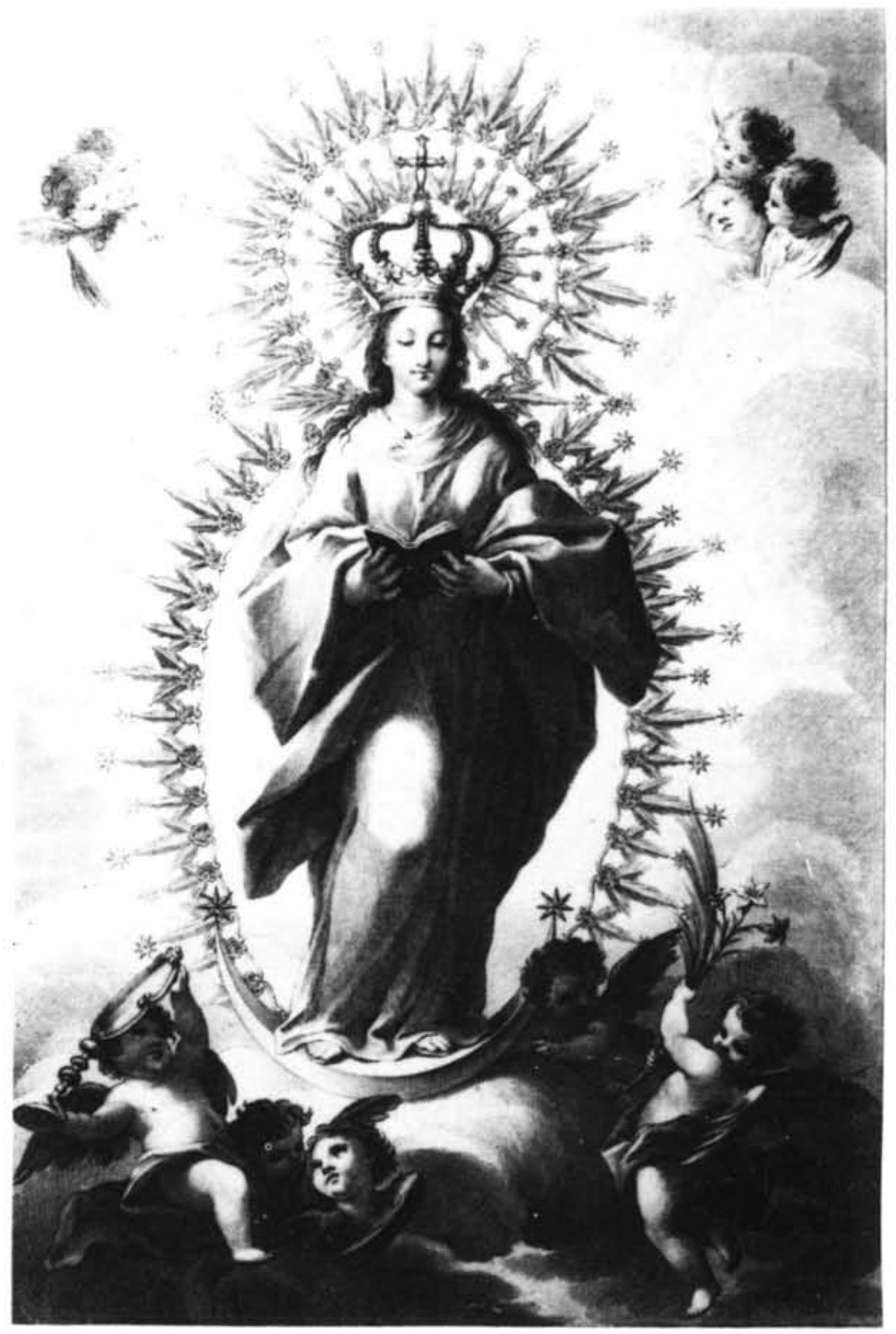

Fig. 5. Versión idealizada de la Concepción llamada "La Sevillana" que preside el Retablo Mayor de la Iglesia de San Buenaventura según un grabado de 1897. 


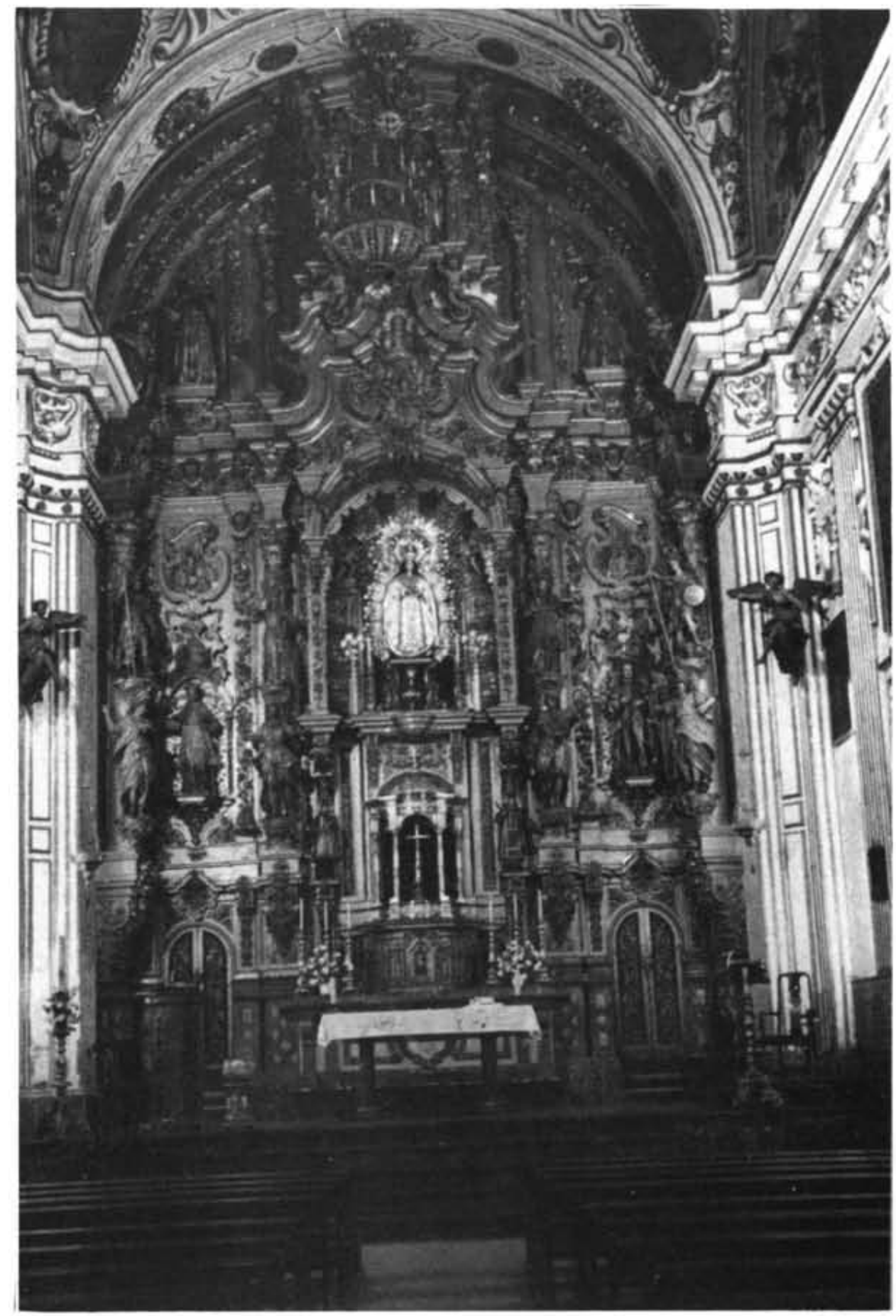

Fig. 6. Actual Retablo Mayor de la Iglesia Conventual de San Buenaventura que vino a sustituir en la última restauración del templo a la obra de José Fernandez. 


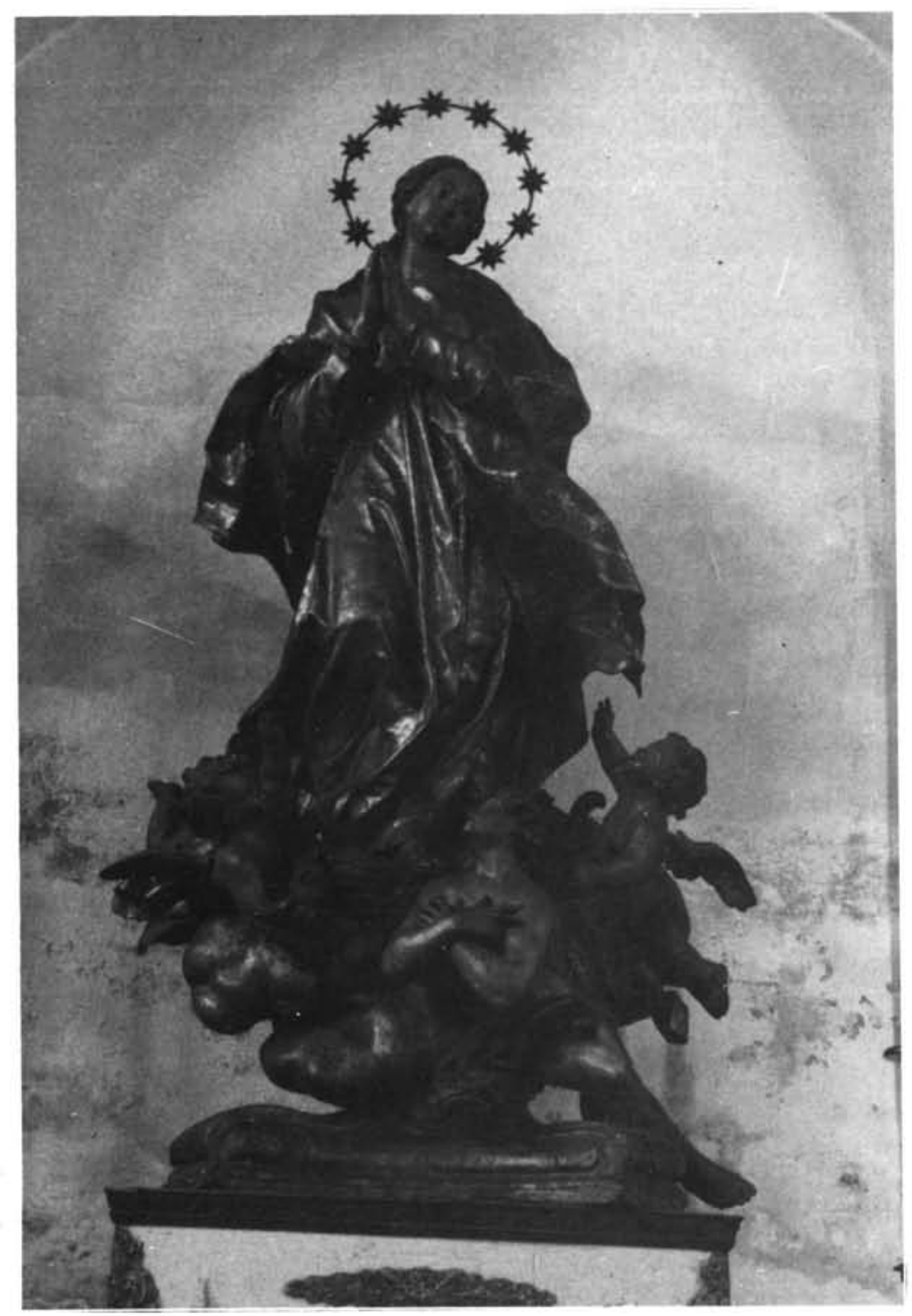

Fig. 7. Inmaculada de escuela Italiana (posiblemente napolitana), del s. XVIII. Estuvo presidiendo el retablo mayor de San Buenaventura, hasta la reposición de la "Sevillana", y entonces pasó al altar del Sagrario de dicha iglesia. Foto Nandín. 4-10-1916. (Cliché: Laboratorio de Arte). 